\title{
Extreme right parties in Europe today: definition and electoral performance
} Aline Burni

\author{
Aline Burni Pereira Gomes \\ Doutoranda em Ciência Política pela \\ Universidade Federal de Minas Gerais \\ e pela Université Catholique de Louvain \\ E-mail: alineburni@gmail.com
}

\begin{abstract}
Since the 1980's, many European countries known for their consolidated democratic systems, have experienced the unexpected electoral emergence of so-called extreme right or populist radical right parties. With the development of recent elections in the Netherlands, France, Germany and Austria, extreme right parties such as the Dutch Party for Freedom (PVV), the French National Front (FN), the Alternative for Germany (AfD) and the Freedom Party of Austria (FPO) have attracted attention both from the media and in academic investigation, because of their radical and populist appeals, as well as their relevant electoral results. What do these parties have in common? Do they belong to a single party family? More recently, what has been their electoral support in different countries and types of elections? To contribute to introductory comparative understanding about this topic, this paper will examine the existing literature, and analyze descriptive electoral data of recent contests. The aims of this work are twofold. First, it intends to provide theoretical background about discussions on the terminology and party family definition, which will be done grounded on the specialized literature. I argue that extreme right parties can be defined based on three features: identitarian politics, authoritarian values and a populist style. Second, this work assesses the current electoral performance of main extreme right parties across European countries, using descriptive data collected from three platforms: "ParlGov", "Parties and Elections in Europe" and "European Elections Database".
\end{abstract}

\section{Keywords}

extreme right, political parties, populism, European politics, elections

\section{Resumo}

Desde a década de 1980, muitos países europeus, conhecidos por apresentarem sistemas democráticos consolidados, passaram pelo inesperado surgimento eleitoral dos chamados partidos de extrema direita ou partidos populistas de direita radical. Com as recentes eleições ocorridas na Holanda, França, Alemanha e Áustria, partidos de extrema direita como o Partido pela Liberdade Holandês (PVV), a Frente Nacional Francesa (FN), a Alternativa para a Alemanha (AfD) e o Partido pela Liberdade da Áustria (FPO) atraíram tanto a atenção da mídia, como também despertaram investigações acadêmicas, devido a suas propostas radicais e populistas e resultados eleitorais relevantes. O que esses partidos têm em comum? Eles pertencem a uma única família partidária? Recentemente, qual tem sido seu apoio eleitoral em diferentes países e tipos de eleições? Para contribuir para uma compreensão introdutória, em perspetiva comparada, sobre este tema, este artigo examinará a literatura e apresentará os mais recentes resultados eleitorais dos partidos de extrema direita em alguns países europeus. Este trabalho possui dois objetivos. Em primeiro lugar, pretende fornecer um embasamento sobre a discussão teórica a respeito das terminologias e definições da família partidária de extrema direita, o que será realizado recorrendo-se à literatura especializada. $\mathrm{O}$ argumento aqui apresentado é que os partidos de extrema direita podem ser definidos com base em três características centrais: política identitária, valores autoritários e estilo populista. Em segundo lugar, este trabalho avalia o atual desempenho eleitoral dos principais partidos de extrema direita em países europeus, utilizando dados coletados a partir de três plataformas: "ParlGov", "Parties and Elections in Europe" e "European Elections Database".

\section{Palavras-chave}

extrema direita, partidos políticos, populismo, política europeia, eleições 
Aline Burni

\section{Introduction}

Since the middle 1980's there is a new group of parties located on the right of the political spectrum which have been calling the attention of analysts because of their accelerated electoral growth and radical proposals in the context of established democracies. At first, they have been assimilated to old fascist movements, but soon it has been possible to understand that their strategies, issues, and constituencies were very different from those of interwar movements. Two main disparities of new extreme right parties when compared to fascism are that the former addresses post-industrial issues (IGNAZI, 2006), including immigration, globalization and the European Union, and they compete elections as their main way to access power (NORRIS, 2005). This paper will address the extreme right phenomenon in Europe today, firstly presenting the characteristics of the context in which those relatively young parties have emerged, and their differences regarding fascist movements from the 1920's and 1930's. Secondly, I will introduce some debates found in the literature concerning the terminology and definition of the extreme right party family, arguing that they share common positions, and explain why it is considered that "extreme right" is the best way to call them, like suggested by many authors, including Ignazi (2006), Hainsworth (2008) and Harrison and Bruter (2011). In my view, extreme right parties could be defined by three features: identitarian politics, authoritarian values and a populist style. I will discuss them further in this work.

This definition is not entirely new, but based on one of the most applied conceptualizations introduced by Cas Mudde (2007), who refers to this party family as "populist radical right", defining it as having a threefeature ideological core: nativism, authoritarianism and populism. Although I propose slight variations in this definition, Mudde (2007) has offered three crucial dimensions under which other understandings advanced by several other authors could also be interpreted. However, I think that identitarian politics is a better term to capture the salience of cultural and identity issues in extreme right party's programs and strategies. This term is also able to include other types of pursuit for a mono-cultural society, not only restricted to national homogeneity, but also forms of regionalism. And, contrary to Mudde (2007), I believe that the populist feature is not exactly an ideology, but instead a political style.

Thirdly, I will present a general figure of current electoral performance of main extreme right parties is European countries using descriptive electoral data collected from three platforms: "ParlGov", "Parties and Elections in Europe", and "European Elections Database". On the last section of this paper I will address the main conclusions and suggest some areas for future investigation.

\section{Context of emergence and distinction from fascism}

One possible confusion that emerges when one studies the current phenomenon of extreme right parties in Europe refers to its differences or similarities to fascism and Nazism. Firstly, this confusion arises because both movements belong to the extreme right tradition of thought (IGNAZI, 2006), and secondly, because some post-industrial extreme right parties are originally rooted in former fascist movements, such as the Italian Social Movement (MSI), the Freedom Party of Austria (FPO) or the French National Front (FN). In this section, I will try to address what sets fascism and the contemporary extreme right apart.

To start, it is important to emphasize the distinct historical contexts in which each phenomenon has emerged. Fascism as a movement appeared specifically in Italy in the 1920s, having been founded by Benito Mussolini. The historical context at that time was characterized by the social and economic problems resulting from the end of World War I, when the country faced serious economic issues, such as an accelerated increase on inflation and unemployment. Italy, as a late industrialized country, was going through an economic transition, by that time still a predominantly agrarian nation. Some years later in Germany, a country equally overwhelmed by misery, social crisis and the demoralization of its people due to the responsibility for the world conflict, the National Socialist movement has also been launched, presenting similar ideological and organizational nature as fascism.

Nazism is considered one variety of fascism and both are revolutionary movements that aimed to overcome what they have considered as structural constraints of liberal-capitalist societies. Their ideological foundations are, however, historically prior to their organization as political movements, dating back to the reactions against progressive European revolutions that took place in the nineteenth century. Such foundations are part of a broader post-revolutionary intellectual reaction against the Enlightenment (IGNAZI, 2006). By 
opposing the conception of equality, anti-Enlightenment thought is radically conflicting with liberal politics and modern democracy (FINCHELSTEIN, 2008).

The extremist right-wing movements created in the 1920s and 1930s were essentially anticommunist, against economic liberalism, marked by violence, the defense of a corporatist organization of society, and classical racism, based on the biological features of individuals. Economically, they represented a third-wave between capitalism and socialism (IGNAZI, 2006). Specifically in the case of Nazism, it defended the myth of racial purification, a view in which the nation was associated with ethnic unity and the Aryan race would be considered superior to the others. The Nazi empire should ideally be created around a single population, and all those who were not considered part of that community, from an ethnic point of view, should be excluded or eliminated (RODOGNO, 2008).

Nazi-fascist movements explicitly opposed liberal democracy and would make use of force to advance their political goals. Therefore, they have been linked to highly armed and disciplined paramilitary organizations responsible for the persecution of their opponents, mainly socialists and communists. Like the Italian Fascist Party, the German National Socialists assumed themselves as the defenders of the order against the so-called "red danger". Despite some minor differences, three points united Nazism and fascism: expansionism, anticommunism and anti-Semitism (RODOGNO, 2008).

By its turn, the contemporary emergence of extreme right parties in Europe has taken place in a very different socioeconomic and political context (KITSCHELT; MCGANN, 1995). While Nazi-fascism emerged in societies in transition to capitalism and liberal democracy, just after the end of World War I, and at a time when this political-economic system was still very fragile, the new extreme right emerged in advanced industrial societies, where consolidated representative democracies predominate. Additionally, the later emerged in a world that was about to witness the end of the Cold War, therefore, communism was already very weakened ideologically, compared to the post-World War I period.

In this sense, the importance that anti-communism represented for the old extreme right is not found to the same extent and with centrality among new extreme right parties, whose main preoccupations are more specific to their own time. With the end of the Soviet Union in 1991, opposition to communism ceased to be a central issue for emerging radical right-wing ideologies. However, new extreme right parties also have their "enemies", such as Islam, ethnic minorities like Roma, the European Union, or the political elite (MUDDE, 2007; LAUDE, 2011).

The macro-sociological context in which the new extreme right-wing parties emerged is marked by the advancement of globalization, the questioning of an old and established representative democracy, multiculturalism and immigration flows, phenomena that have been absent when Nazi and fascist movements and parties emerged. For instance, the construction of the European Union considerably modified the identities shared by the countries of the continent, as well as the room for maneuvering of national governments (KITSCHELT, 2000). To a certain extent, the European Union created a shared notion of belonging, which have been later expanded to the East and South of the continent, and has the potential of unifying different nations towards common objectives, something that was not conceivable in the inter-war period.

Prowe (1994) highlights six crucial features of postwar European societies to which contemporary extreme right parties are confronted with: multicultural societies, decolonization and its violent episodes, an extended period of peace, a stable and prosperous consumer society, broad acceptance of democratic norms and intense urbanization. In this sense, the old and the new extreme right are very different from each other, for they are each specific to their own historical environment, deeply modified over the decades. They develop their proposals and programs in response to the circumstances of their time, according to Hainsworth (2008: 2):

The contemporary extreme right has emerged in socio-political and historical circumstances that are very different to the pre-war and war-time ones. Notably, liberal and capitalist democracy has become more embedded in Western Europe, and the international climate has evolved from Cold War to thaw, to take in the "fall of the wall" and the retreat from communism.

Most of the new extreme right parties were born in the 1980s and 1990s, some of them were still created in the 1970s, as in the case of the French National Front, one of the oldest. They started to gain more significant electoral support in the mid-1980s and they frequently avoid the term "party" in their names, because in their interpretation this word creates divisions in society, while they expect society to be 
homogeneous and united. They prefer to call themselves "Fronts" or "Blocks", and they usually apply normative words such as "Democracy", "Freedom", "Progress" and "People" on their labels (HAINSWORTH, 2008). Although some of them have origins linked to former fascists groups, they clearly try to distance themselves from the fascist stereotype, perceived very negatively by public opinion in European societies (IGNAZI, 2006). In order to do so, many parties have replaced their old leadership, expelled extremist members and adopted new communication strategies. A recent example is the French National Front, which since 2011 has a friendlier leader on charge, Marine Le Pen, and its name has just been changed to National Rally (Rassemblement National), in 2018.

In Kitschelt and McGann's view (1995), none of the new extreme right parties corresponds to the old fascist ideology, because there are differences in the electorate and the demand for these parties, as well as in their origins and organizational structure. Both can be located on the far right of the political-ideological spectrum (IGNAZI, 2006), but they do not represent the same ideas and projects of societies. The fascist project aimed at defeating liberal democracy, but the contemporary extreme right is compatible with its basic formal principles, even though authors argue that it is ideologically anti-liberal (BETZ; JOHNSON, 2004). Fascist parties belong to the extreme right tradition, but not every extreme right party should be considered fascist or Nazi. In this sense, Ignazi (2006) creates a typology of extreme right parties referring to two ideal-types: the "old" and the "post-industrial" extreme-right. In his view, both are right-wing essentially because they are antiegalitarian, but the post-industrial extreme right is also anti-system and addresses issues that emerged in postindustrial societies.

Another factor that distinguishes the old and the new extreme right is their time-horizon orientation. Nazi-fascism was forward-looking and intended to completely break with the existing social order, installing an entirely new model of society. It considered that society was about to undergo a profound change, a true renaissance, which was called by Grifin (1991, apud RYDGREN, 2008) "the palingenetic myth." The new extreme right, on the other hand, does not explicitly intend to replace the current system with a new order, but rather to promote punctual changes in society and politics, albeit drastic ones. These parties are primarily oriented to the past - or an idealization of the past -, and they desire the restauration of a past status quo, intimately tied to national cultural tradition (RYDGREN, 2008).

The new extreme right parties, in opposition to the old Nazi-fascist movements, accept liberal democracy and do not use organized violence as a means to get to power. Their main competition arena are elections, and they present themselves as actors who accept the rules of the democratic game, without relying on violence, which has been an element very characteristic of the Nazi and fascist movements (IGNAZI, 2006).

With regards to hostility towards certain groups perceived as "enemies", the new extreme right adopts the logic of the "right to difference" to justify anti-immigration proposals or opposition to ethnic minorities, unlike the classic racism defended by Nazi-fascist movements. The idea of the "right to difference", inspired in the ideology of the Nouvelle Droite (IGNAZI, 2006), argues that in order for peoples to preserve their right to be different from each other, they must be kept separate. It is a distinct conception from biological racism, by its turn based on the biological superiority of one race over others. The concept of "right to difference" justifies the separation of groups based on cultural differences, and the need to preserve traditions, not explicitly on biological superiority of one group over another. This framework introduces the idea that some groups are incompatible with others, and assimilation of customs and values is impossible among them. While race was at the core of classical racism, culture is at the center of modern discrimination carried out by the extreme right. The first model advocated the subordination of certain races to others, while the second model advocates a culturally homogeneous community through the expulsion of those who do not share the same set of customs, traditions and values.

The old and the post-industrial extreme right also differ regarding their political support. While most part of the fascist supporters came from the middle class, or the petty bourgeoisie, being concentrated in rural areas, the post-industrial extreme right emerged in urban centers and is currently particularly attractive to popular social strata, low-skill workers, younger and less formally educated people, particularly starting from the 1990s (LUBBERS; SHEEPERS, 2002).

Although corresponding to different phenomena, there are some common elements between fascism and the post-industrial extreme right. Both are nationalist, although the new extreme-right is not expansionist. Both are linked to a populist style, which emphasizes a deep and irreconcilable division between the people and the elite, using an anti-political rhetoric, and a polarizing and charismatic discourse. They are equally anti- 
Aline Burni

pluralist and anti-liberal, because they oppose diversity, consensus-making and dialogue between parties. Finally, they attribute a stronger importance to the collective body instead of individuals. In this sense, they display an authoritarian character, advocating for a strong state which controls social behavior, severely punishes criminals, and enforces law and order.

As a conclusion of this section, the political and socioeconomic contexts in which the current extreme right parties emerged are very different from the post-World War I era. This makes their orientations, strategies and support also very distinct from each other. While fascist and Nazi movements were anticommunist, expansionist, anticapitalistic, violent and overtly racist, contemporary extreme right parties operate in a context of consolidated liberal-democracy, so they run elections and accept the rules of the game. This does not mean that they hold substantive democratic values. As will be seen in the next section, the extreme right party family embraces positions that can challenge democratic principles, even though they defend their project through democratic participation into elections.

\section{Is there a party family? Terminology and definitional debate in the literature}

The emergence of contemporary extreme right parties is a relatively new phenomenon, that began to be more attentively studied in the field of Political Science starting from the 1990's. Considerable progress has been made regarding the identification of features of extreme right parties and potential factors that account for their emergence and electoral success. Today, the extreme right is the most studied party family of all (MUDDE, 2016; GOLDER, 2016). However, there is no consensus about how to define it and which core characteristics should be examined to classify a party as part of the group. Operationalization is usually absent in several classifications, and issues of empirical definition often emerge because many studies focus on an ideal-type or few case-studies to provide a party family definition (HARRISON; BRUTER, 2011). This approach makes it hard for the provided definition to travel to different contexts.

Moreover, attention has been called to the heterogeneity of this party family, which can accommodate sub-types according to some scholars (GOLDER, 2016; HARRISON; BRUTER, 2011; IGNAZI, 2006). In general, academics consider that there exists an extreme right party family, but it can be called or defined by applying distinct approaches and criteria. Many terminologies are used by different authors to refer to this group of parties, which nevertheless frequently include a similar core of individual political parties in it (but are not restricted to them), for instance the French FN, the Austrian FPO, the Italian MSI-AN and the Belgium VB.

Terminologies most frequently used are "extreme right" (ARZHEIMER, 2009; HAINSWORTH, 2008; HARRISON; BRUTER, 2011; IGNAZI, 2006; LAUDE, 2011; MUDDE, 2000; PERRINEAU, 2011;) and "radical right" (KITSCHELT; MCGANN, 1995; NORRIS, 2005; GIVENS, 2005; STOCKEMER, 2017). There are other expressions that refer to the same phenomenon, such as "new national populism" (TAGUIEFF, 2012), "populist right" (EISMANN, 2002 apud MUDDE, 2007), "populist radical right" (BETZ; JOHNSON, 2004; MUDDE, 2007), "anti-immigration/anti-immigrants parties" (VAN DER BRUG; FENNEMA, 2007), "new radical right" (RYDGREN, 2008) or "far right" (GOLDER, 2016). These are only some examples to illustrate the range of existing names given to the same party family. Unfortunately, I will not be able to explain why each one of them work or not in this paper. Instead, I will argue that even if names, definition and core characteristics vary among scholars, it is possible to find a set of recurrent features in the literature to define this party family, synthetized in three elements: identitarian politics, authoritarian values and populism.

This set of qualities is not new to define the extreme right, and it is very close to the definition previously provided by Mudde (2007). However, I prefer to apply the term "identitarian politics" rather than "nativism", because it includes not only the nationalist and xenophobic profile of such parties, but it also expresses their concern to increase the salience of identity issues in politics. In contrast to Mudde (2007), I also prefer to consider populism as a political style, not an ideology.

To a certain extent, the debate to establish a common terminology lies on the disputes about the definition of the party family, which in its turn relies on the constitutive elements and essential features for classifying a party as part of the group. An important part of studies on the topic does not provide a clear and operational definition. Many of them rely on numerous abstract concepts or adopt an existing definition created by another author, without further questioning it. Few studies present a list of individual political parties that they include in the party family (MUDDE, 2007; NORRIS, 2005; HARRISON; BRUTER, 2011; STOCKEMER, 2017). Furthermore, most works do not rely on an empirical definition. The main problem with lack of clear 
Aline Burni

definitions and the interchangeable use of distinctive terms referring to identical phenomena is that it undermines the ability to compare (MUDDE, 2007).

For some authors, what I call extreme right can be essentially defined based on the position that parties occupy in the political spectrum, so it apprehends parties considering their spatial location in relation to other parties of the political system. For instance, this is the definition used by Pippa Norris (2005) and Klandermans and Mayer (2006). According to this relative definition, extreme right parties would be the ones placed on the most right-wing position in a party system (STOCKEMER, 2017). Norris (2005) operationalizes this definition by selecting political parties placed on a position equal or higher than 8 in the political spectrum, on a scale ranging from 0 (left) to 10 (right).

In my opinion, three misleading conceptions are implicit in this approach. First, it suggests that extreme right parties do not necessarily defend similar policies or share a common core. Second, it implies that they can be defined based purely on the classic unidimensional left-right divide of electoral competition, whereas it has been discussed that this uni-dimensionality is largely insufficient to understand party competition in many countries now (BORSCHIER, 2010). And third, it also gives the idea that extreme right parties should be defined on spatial terms restricted to their own national political system, while it is known that many of them exchange support internationally, and adopt similar strategies from their neighboring counterparts. So, in this sense, they do participate in an international network (MUDDE, 2007), even if it is an informal one, which raises the need to also understand them in the international context. One of the methodological issues that this approach raises is that it can be hard to distinguish between extreme right and mainstream right parties that are more radical. They could both be placed on the far right of the spectrum in a given political system, although not sharing all characteristics, and belonging to separate groups.

Another way to define extreme right parties is grounded on their political style, so the focus here is not placed on spatial terms, but on a specific strategy they use. This approach usually highlights their "antisystem", "anti-establishment", "populist", "outsider" or "niche" profile. Authors that conceive the extreme right this way tend to emphasize the criticism that they hold towards mainstream parties, the establishment, as well as their mobilization based on citizens' disappointment with politics. Those are the factors considered as being what differentiates extreme right parties from other, in some authors' view (SCARROW, 1996; PELINKA, 1998).

Ignazi's (2006) definition mixes anti-system discourse and the defense of certain values to characterize the extreme right, but emphasizes the former to distinguish between the post-industrial extreme right type. He considers the existence of two sub-types of extreme right: the old and the post-industrial one. The first one has an ideology that refers to one of the established right-extremist traditions of thought, called by the author an "ideology in a strong meaning". The second one presents an anti-system discourse, better understood as an "ideology in a weak meaning". Ignazi (2006) argues that post-industrial extreme right parties hold a system de-legitimizing discourse, are a by-product of the conflicts of post-industrial society, and react to the emergence of new conflicts defending the natural community from alien and polluting presence (racism, xenophobia), demanding for law and order, and expressing uneasiness over representative mechanism and procedures.

To a certain extent, this conception sees extreme right parties as destined to an eternal opposition, and does not foresee them arriving into power, or taking part in governments. But, as it is known, this has already happened in some cases, like in Austria, Italy, Denmark, Poland, Finland, Switzerland, and Hungary, for example. This perspective frames extreme right parties as mainly an opposition to the current political order, but not as actors who bring certain conceptions of the world, or proposed solutions into the political competition.

A third way to look at this party family considers that it has a common core ideology, program or discourse. In other words, what gathers extreme right parties into a single family is the content of their policies. This approach is currently most found in the specialized literature. However, there is again a vast range of defining ideological features, some authors consider a long list of necessary conditions for classifying parties as extreme right, while others reduce this number to a consistent core. From various ideological definitions of the extreme right party family, two aspects can be highlighted here: such entities attribute high salience to cultural issues, and their ideological conceptions can be in tension with the principals of liberal democracy, even though they are compatible with procedural democracy (BETZ; JOHNSON, 2004).

Early definitions of the extreme right attributed to them the defense of a free-market economy combined with certain socio-cultural positions. In the view of Kitschelt and McGann (1995), the free-market 
Aline Burni

preferences were combined with particularistic-authoritarian values. For Eatwell (1989), economic liberalism was combined with a moral conservatism and political authoritarianism.

Later, it has become a consensus that extreme right parties attribute much more emphasis to sociocultural positions than to specific economic policies (GOLDER, 2016) and that their appeal relies heavily on questions of culture, values and identity (BETZ; JOHNSON, 2004). Simon Bornschier (2010) interprets their rise as a consequence of the growing salience of a new conflict divide taking place in Western Europe, which is based on a cultural-values divide that opposes a libertarian-universalistic position to a traditionalcommunitarian one. A libertarian-universalistic position favors multicultural and open societies. It defends the individual freedom and minority rights, being in favor of issues such as abortion, minorities' rights and gender equality. On the other hand, traditional-communitarian positions show a preference for more closed and culturally homogeneous societies, attributing high importance to traditional identities and customs, such as family and the nation-state.

Extreme right parties highly mobilize on the cultural dimension, they share a homogeneous set of cultural preferences, but diverge regarding the intervention of the state in the economy. For some authors, their blurring positions when it comes to economic policies is, in fact, seen as a powerful and deliberately chosen electoral strategy (ROVNY, 2013).

Some definitions mix ideological elements with style components, but employ rather abstract concepts and do not provide an empirical approach. Betz (1994: 413), for example says that extreme right discourse is a "rejection of socio-cultural and socio-political systems... and of individual and social equality". By its turn, Fennema (1997) considers that there are four key features of extreme right ideology: ethnic nationalism (or ethno-culturalism), anti-materialism, anti-parliamentarianism, and the formulation of conspiracy theories. Paul Hainsworth (2008) associates numerous ideas to the extreme right, but it is not clear if they are all necessary conditions to classify an individual party as such. For instance, he talks about anti-egalitarianism, antiuniversalism, populism, nationalism, a location in the right-most position, anti-parliamentarianism, antipluralism, advocacy for direct power, security, etc.

Harrison and Bruter (2011) analyze ideological discourse in party documents and conclude that there are four subtypes of extreme right parties. The party family in question differently prioritizes two structural ideological dimensions: authoritarianism and negative identity. They consider that there are two ideological conceptions in each dimension: "the authoritarianism dimension has a social (reactionary) mode and an institutional (repressive) conception. The negative identity dimension has cultural (xenophobic) and civic (populist) conceptions" (HARRISON; BRUTER, 2011: 22). The reactionary conception of the authoritarian dimension is described as a belief that the state has an authority over the individual, an emphasis on the existence of a natural community, limitations on personal and collective freedoms and the acceptance of hierarchy to organize society. The repressive conception of authoritarianism leans towards oppressive measures to assure strict obedience and state authority. Regarding the negative identity dimension, its xenophobic conception means the exclusion of those seen as essentially different to the community, namely foreigners. The populist conception, on the other hand, centrally expresses a contempt for fellow politicians and their parties. Populism is basically understood as a simplistic discourse that relies on the sovereignty of the people and the denunciation of political elites and institutions. The combination of each of the two conceptions in each dimension generate four subtypes of parties within the extreme right party family, according to the authors. My critique to this conception is that xenophobia and populism are characteristics that can perfectly coexist - and usually do - among contemporary extreme right parties.

Betz and Johnson (2004) also provide a definition based on a core ideology. They consider that contemporary populist radical right parties are fundamentally anti-liberal, but compatible with basic formal principals of democracy, unlike the traditional postwar radical right. In their view, right-wing populist ideology is anti-elitist, exclusionary and openly discriminatory. Anti-elitism means that they appeal to the common sense and the ordinary man. Exclusionary refers to the right to difference and identity, so they believe that peoples and nations should have the right to keep their traditional identity. And open discrimination is illustrated by the promotion of "national preference", meaning that they defend that priority over economic and political resources should be given to natives over foreigners.

Among this confusing and fuzzy set of explanations, the definition provided by Cas Mudde (2007) has been increasingly used by scholars (ROODUIJN, 2015; MUIS; IMMERZEEL, 2016). It has very well captured three broad dimensions that translate what the literature has been fluidly articulating about the character of 
Aline Burni

the extreme right party family: nativism, authoritarianism and populism, in the author's terms. Each of them are taken as an ideological feature that defines what he calls "populist radical right".

Nativism combines nationalism and xenophobia and excludes liberal forms of nationalism. The idea underlying nativism is the conception that "states should be inhabited exclusively by members of the native group ('the nation') and that non-native elements (persons and ideas) are fundamentally threatening to the homogeneous nation-state. The basis for defining (non) 'nativeness' can be diverse, e.g. ethnic, racial or religious, but will always have a cultural component" (MUDDE, 2007: 19). Authoritarianism does not mean opposition to the liberal democratic order, or the desire to replace the democratic regime with an authoritarian system. Instead, it means adhesion to authoritarian values and beliefs. In his words, "authoritarianism is defined here as the belief in a strictly ordered society, in which infringements of authority are to be punished severely. According to this interpretation, authoritarianism includes deep concerns with law and order, and the defense of 'punitive conventional moralism"' (MUDDE, 2007: 23). Lastly, populism is defined by Mudde (2007) as a "thin-centered ideology that considers society to be ultimately separated into two homogeneous and antagonistic groups, 'the pure people' versus 'the corrupt elite', and which argues that politics should be an expression of the volonté générale (general will) of the people" (MUDDE, 2007: 23).

Yet, I think populism is better apprehended as a political style that applies a discourse opposing "the people" and "the elite", and criticizes the establishment, rather than an ideology itself. Populist strategies can vary from context to context, and can be applied by extreme right parties to different extents on different periods. But it can also be employed by other political parties, either mainstream or extreme leftist. Ideologies usually refer to more structured and long-term ways to approach things, but populism seems much more volatile, flexible and short-term. Additionally, I have not been able to find in the present literature a consistent criterion to empirically identify a populist ideology. In other words, which policies or structures of discourse should one expect to find in order to identify a populist ideology?

Furthermore, I understand that the term "identitarian politics" would be better than "nativism" to interpret the search for a culturally or ethnically homogeneous community by the extreme right, and their opposition to foreigners or minorities. Some extreme right parties are not explicitly nationalist, they can also defend the sovereignty of a region, for example, as it is the case of the Italian Northern League (LN) and the Flemish Interest (VB).

Some extreme right parties in Eastern Europe are traditionally more worried with national minorities than with immigrants. The term "identitarian politics" is useful to capture their emphasis on identity issues compared to economic issues, and it expresses their effort to explore this cultural cleavage in political competition.

Finally, the term "extreme right" offers a series of advantages when referring to this party family. According to Ignazi (2006: 30) "first, it recalls the notion of extremeness in a political and ideological space: extreme right denotes those issues and organizations that are close to one extreme of the political spectrum. Secondly, the extremeness is related to the 'anti-system' values-set". In other words, this term elucidates that extreme right parties hold positions much closer to the "authoritarian" values pole (KITSCHELT; MCGANN, 1995) or the "traditional-communitarian" values pole (BORSCHIER, 2010) than other parties in the system. It also expresses the idea that they embrace positions and conceptions fundamentally hostile to liberal democracy, like their anti-egalitarian, anti-universalist and anti-pluralist appeals. This way, "extreme right" is an adequate term to be employed because it translates the idea of those parties being as more radical than others regarding cultural issues, and it reflects that their positions are in tension with democratic values.

\section{Electoral performance}

The literature points to the fact that there is an extreme right party family, but this does not mean that all parties in the group share the same trajectory. This family can also be very heterogeneous regarding certain positions, for example concerning rights of homosexuals or the withdrawal from the European Union. Some extreme right parties hold more liberal economic proposals than others, as in the case of Scandinavian parties, while others are clearly protectionist, illustrated by the French FN. Their electoral performance can also drastically contrast, even though some trends have been observed by experts on the topic: their electoral breakthroughs occurred mainly in the mid-1980s, particularly in sub-national (regional or local) and/or European elections (BETZ, 1994; NORRIS, 2005; MUDDE, 2007). Many works on the subject matter present the historical development of extreme right parties' performance, so here I will focus on their most recent 
EXTREME RIGHTS PARTIES IN EUROPE TODAY: DEFINITION AND ELECTORAL PERFORMANCE

Aline Burni

electoral results in national legislative and presidential elections, as well as elections for the European Parliament.

Between the end of World War II and the middle 1980s, extreme right parties used to get very insignificant electoral results, holding a marginalized position in virtually all European party systems. Although their electoral growth has been different across countries, varying over time, and among types of elections, what seemed to be an isolated and erratic voting during the 1970 s, turned into a relatively constant phenomenon in European politics starting in the middle 1980s, with the multiplication of parties across countries, and their electoral growth (NORRIS, 2005). In the past, these entities struggled to pass the electoral threshold. By contrast, today they seriously compete for power, and have a considerable political influence, having participated or supported governments in the cases of Italy, Austria, Switzerland, Norway, the Netherlands, Denmark (DE LANGE, 2008), Hungary, Poland, and Finland.

Pippa Norris (2005) explains that between the 1980s and 2000s, popular support for these parties has tripled and, by the beginning of the 2000s, one in six European voters would chose an extreme right party to which cast their vote. When one looks to the average development of this party family's vote share in Western Europe, the progressive trend is clear, as it is illustrated in graph 1 below.

\section{Graph 1: Average vote share of extreme right parties in Western Europe (\%)}

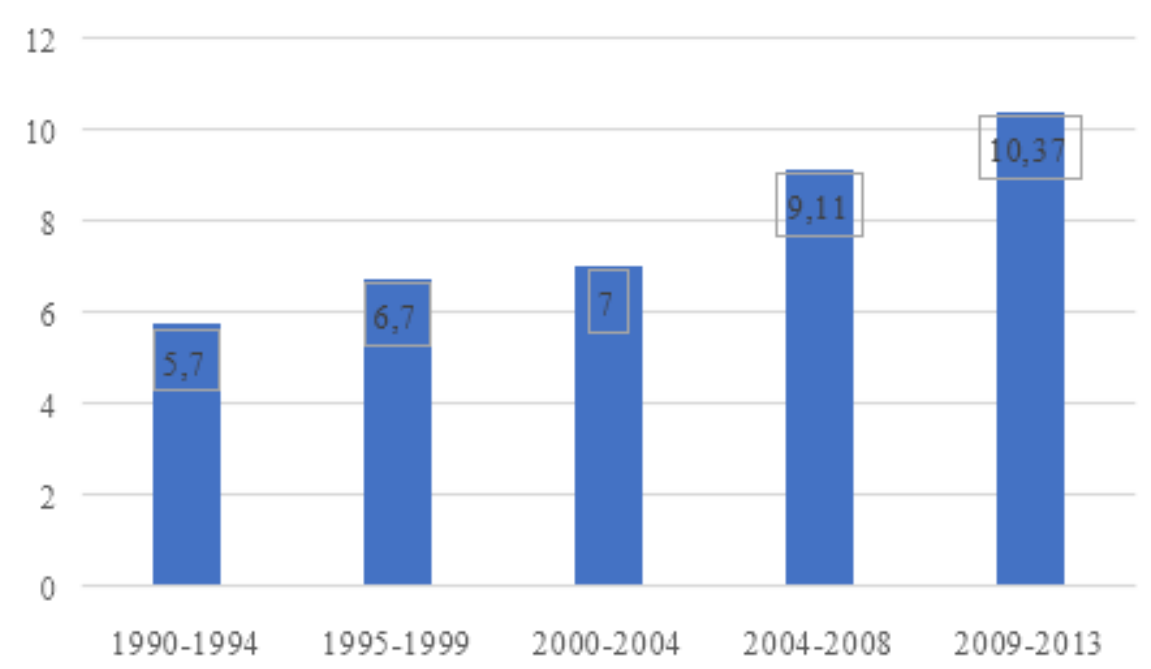

Source: Percentages found in STOCKEMER, 2017: 14

In some countries, extreme right parties have shown a consistent and sustainable electoral support over the last decades, prominent examples being the FN in France and the FPO in Austria. In both cases, they have survived oscillations in their trajectories, they have gone through a renewal of strategies, leadership change, and an internal fraction. Both the FPO and the FN, however, have been able to impose themselves as the main extreme right competitor in their national party systems, marginalizing their newly-created extreme right challenger originating from the internal division. They were both strongly present in the second round of the last presidential elections, in 2017 in France, and in 2016 in Austria. On the same occasion, they also achieved their higher support ever on a national level election (in the $2^{\text {nd }}$ round): Marine Le Pen (FN) got $33.90 \%$ of the votes, and Norbert Hofer (FPO) got $46.20 \%$.

Nevertheless, in other countries, extreme right parties have been traditionally marginalized in the electoral arena, and consequently they have been absent from governments, such as in Spain, Greece, Portugal, the United Kingdom and Ireland. Until very recently, Germany was also part of this group, but the newly founded Alternative for Germany (AfD) obtained 13.3\% in the 2017 legislative elections and made a first-ever entrance of an extreme right party in the German Bundestag since 1933. Other German parties frequently included in the extreme right category have been The Republicans (REP), the German People's Union (DVU) and the National Democratic Party of Germany (NPD), but their vote share has been historically 
EXTREME RIGHTS PARTIES IN EUROPE TODAY: DEFINITION AND ELECTORAL PERFORMANCE

Aline Burni

very low, and they haven't achieved the 5\% threshold required to get representation in the German parliament.

Furthermore, there are some cases of flash electoral success, followed by an equally sudden disappearance, as it has happened with the List of Pin Fortuyn (LPF) in the Netherlands. In 2002, the leader of the recently founded LPF was murdered just before the general election, and a sudden surge of support for his party took place. As the second largest party in 2002, already in their first attempt, the LPF entered parliament and participated in the coalition government led by the Christian Democrats. However, their success did not last long, and in the following 2003 election, the LPF decreased its support from $17 \%$ to $5.7 \%$, which suggests that 2002 was a deviating election (NORRIS, 2005). A close tendency of extreme right remains alive in the country. The Party for Freedom (PVV), created in 2006 and headed by one of the most prominent extreme right leaders in Europe, Geert Wilders, has shown a rather stable and relevant support in the most recent legislative and European elections in the Netherlands, gathering 21.2\% of supporters in 2017.

The growth of extreme right parties in Eastern Europe has been even more accelerated than in Western Europe, but investigations focusing on the former region are still more scarce and recent. Such parties are generally younger than their Western counterparts, and their progress has been surprisingly quick in some countries, like in Poland and Hungary, where they became governing parties capturing more than $20 \%$ of voters' choice in recent elections.

Extreme right parties in Eastern Europe are inserted in a different context of younger, more instable and less institutionalized democracies, so comparisons with the phenomenon occurring in Western Europe should be developed with caution. For instance, when comparing extreme right voters in Western and PostCommunist Europe, Allen (2015) argues that there are some important differences between these two regions. Fist, the linkage between anti-immigration attitudes and support for extreme right parties is stronger in Western Europe. Second, this group of voters is less religious in Western Europe than in post-communist countries. Third, post-communist extreme right voters are leftist regarding economic issues, while in the West more rightist attitudes towards income redistribution slightly predict a vote for extreme right parties. Fourth, extreme right supporters in Western Europe are less satisfied with democracy as a regime type.

Table 1 below presents the most prominent extreme right parties in 18 European countries and their most recent results in national legislative elections.

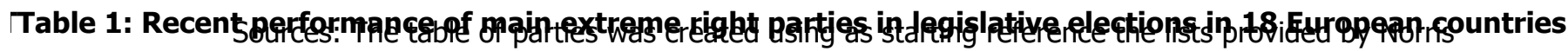

\begin{tabular}{|c|c|c|c|c|c|c|c|c|c|}
\hline Country & $\begin{array}{l}\text { Elector- } \\
\text { al } \\
\text { system }\end{array}$ & $\begin{array}{l}\text { Party name } \\
\text { in English }\end{array}$ & $\begin{array}{l}\text { Abbrevia- } \\
\text { tion }\end{array}$ & $\begin{array}{l}\text { Year } \\
\text { founde } \\
\text { d }\end{array}$ & $\begin{array}{l}\text { Left- } \\
\text { right } \\
\text { posi- } \\
\text { tion }\end{array}$ & $\begin{array}{l}\text { Mean } \\
\text { vote } \\
\text { since } \\
1990 \text { s }\end{array}$ & $\begin{array}{l}\text { Year } \\
\text { last } \\
\text { elec- } \\
\text { tion }\end{array}$ & $\begin{array}{l}\text { Vote } \\
\text { percent- } \\
\text { age }\end{array}$ & $\begin{array}{l}\text { Gaine } \\
\text { d } \\
\text { seats } \\
\text { (total } \\
\text { seats) }\end{array}$ \\
\hline Austria & PR & $\begin{array}{l}\text { Freedom } \\
\text { Party of } \\
\text { Austria }\end{array}$ & FPO & 1956 & 8.3 & 19.78 & 2017 & 27 & $\begin{array}{l}51 \\
(183)\end{array}$ \\
\hline Belgium & PR & $\begin{array}{l}\text { Flemish } \\
\text { Interest }\end{array}$ & VB & 1978 & 9.7 & 8.5 & 2014 & 3.7 & $3(150)$ \\
\hline Bulgaria & PR & Attack & ATAKA & 2005 & 5.5 & 7.69 & 2017 & 9.1 & $7(240)$ \\
\hline Cyprus & PR & $\begin{array}{l}\text { National } \\
\text { People's } \\
\text { Front }\end{array}$ & ELAM & 2008 & 8.7 & 2.39 & 2016 & 3.7 & $2(80)$ \\
\hline
\end{tabular}

(2005) and Mudde (2007), updated with more recent parties found in Harrison and Bruter (2011) also included in the party family. The list was then reduced to parties that gained at least $1.5 \%$ of the votes in at least 2 recent legislative elections, otherwise they are usually included in the "Other" category in consulted sources. The list was also limited due to availability of data in the referred platforms, which misses some countries, 
Aline Burni

\begin{tabular}{|c|c|c|c|c|c|c|c|c|c|}
\hline Denmark & PR & $\begin{array}{l}\text { Danish } \\
\text { People's } \\
\text { Party }\end{array}$ & DF & 1995 & 8.2 & 13.4 & 2015 & 21.1 & $\begin{array}{l}37 \\
(179)\end{array}$ \\
\hline Estonia & PR & $\begin{array}{l}\text { Conservative } \\
\text { People's } \\
\text { Party of } \\
\text { Estonia }\end{array}$ & EKRE & 1994 & & 8.1 & 2015 & 8.1 & $7(101)$ \\
\hline Finland & PR & True Finns & PS & 2011 & & 7.09 & 2015 & 17.6 & $\begin{array}{l}38 \\
(200)\end{array}$ \\
\hline France & $\begin{array}{l}\text { FPTP } \\
\text { (TRS) }\end{array}$ & $\begin{array}{l}\text { National } \\
\text { Front }\end{array}$ & FN & 1972 & 9.7 & 11.63 & 2017 & 13.2 & $8(577)$ \\
\hline Germany & $\begin{array}{l}\text { MMP } \\
(299 \text { PR } \\
+299 \\
\text { FPTP) }\end{array}$ & $\begin{array}{l}\text { Alternative } \\
\text { for Germany }\end{array}$ & AfD & 2013 & 8.7 & 8.65 & 2017 & 12.6 & $\begin{array}{l}94 \\
(598)\end{array}$ \\
\hline Hungary & $\begin{array}{l}\text { MMP } \\
(106 \\
\text { FPTP + } \\
93 \text { PR) }\end{array}$ & $\begin{array}{l}\text { Movement } \\
\text { for a Better } \\
\text { Hungary }\end{array}$ & JOBBIK & 2003 & 8.7 & 8.43 & 2014 & 20.2 & $\begin{array}{l}23 \\
(199)\end{array}$ \\
\hline Italy & $\begin{array}{l}\mathrm{PR}+ \\
\text { majority } \\
\text { bonus }\end{array}$ & League North & LN & 1989 & 7.8 & 6.5 & 2013 & 4.1 & $\begin{array}{l}18 \\
(630)\end{array}$ \\
\hline Italy & $\begin{array}{l}\mathrm{PR}+ \\
\text { majority } \\
\text { bonus }\end{array}$ & $\begin{array}{l}\text { National } \\
\text { Alliance }\end{array}$ & FDI-AN & 1995 & 8.1 & 11.04 & 2013 & 2 & $9(630)$ \\
\hline $\begin{array}{l}\text { Nether- } \\
\text { lands }\end{array}$ & PR & $\begin{array}{l}\text { People's } \\
\text { Party for } \\
\text { Freedom and } \\
\text { Democracy }\end{array}$ & PVV & 2006 & 8.8 & 13.18 & 2017 & 21.2 & $\begin{array}{l}33 \\
(150)\end{array}$ \\
\hline Norway & PR & $\begin{array}{l}\text { Progress } \\
\text { Party }\end{array}$ & FRP & 1973 & 8.8 & 16.1 & 2017 & 15.2 & $\begin{array}{l}27 \\
(169)\end{array}$ \\
\hline Poland & PR & $\begin{array}{l}\text { Law and } \\
\text { Justice }\end{array}$ & PiS & 2001 & 7.7 & 27.22 & 2015 & 37.6 & $\begin{array}{l}235 \\
(460)\end{array}$ \\
\hline Poland & PR & Kukiz'15 & Kukiz'15 & 2015 & 8.7 & 8.8 & 2015 & 8.8 & $\begin{array}{l}42 \\
(460)\end{array}$ \\
\hline Russia & $\begin{array}{l}\text { parallel } \\
\text { voting } \\
\text { (FPTP/PR } \\
\vdots \\
225 / 225 \text { ) }\end{array}$ & $\begin{array}{l}\text { Liberal } \\
\text { Democratic } \\
\text { Party of } \\
\text { Russia }\end{array}$ & LDPR & 1988 & & & 2016 & 13.1 & $\begin{array}{l}39 \\
(450)\end{array}$ \\
\hline Sweden & PR & $\begin{array}{l}\text { Sweden } \\
\text { Democrats }\end{array}$ & SD & 1988 & 8.7 & 5.73 & 2014 & 12.9 & $\begin{array}{l}49 \\
(349)\end{array}$ \\
\hline Switzerland & PR & $\begin{array}{l}\text { Swiss } \\
\text { People's } \\
\text { Party }\end{array}$ & SVP & 1971 & 7.4 & 22.99 & 2015 & 29.4 & $\begin{array}{l}65 \\
(200)\end{array}$ \\
\hline $\begin{array}{l}\text { United } \\
\text { Kingdom }\end{array}$ & FPTP & $\begin{array}{l}\text { United } \\
\text { Kingdom } \\
\text { Independ- } \\
\text { ence Party }\end{array}$ & UKIP & 1993 & 7.8 & 2.37 & 2017 & 1.8 & $0(650)$ \\
\hline
\end{tabular}


EXTREME RIGHTS PARTIES IN EUROPE TODAY: DEFINITION AND ELECTORAL PERFORMANCE

Aline Burni

Europe Database, the left-right position and foundation year were obtained in the ParlGov database. Electoral system was also included here as found in Norris (2005): PR (Proportional Representation), FPTP (First Past the Post), TRS (Two Round System), MMP (Mixed Majority and Proportional).

European Parliament elections have been considered a favoring opportunity for extreme right parties to perform better than they usually do in national elections, particularly because of their proportional character. Such better performance could also be attributed to the "second-order" character of European elections, according to some authors (REIF; SCHMITT, 1980). The idea of "second-order" elections means that voting for the European parliament is generally approached as less relevant than national contests in the eyes of voters, and, therefore, the former is highly driven by domestic issues and dynamics of competition. This way, in EU elections, voters would be more likely to abstain, as well as to express dissatisfaction with their national systems through protest voting. Furthermore, parties of opposition and small parties tend to do well in EU elections (HIX; LORD, 1997).

In the most recent European Parliament elections, extreme right parties have been, for the first time, the most voted in France, the UK and Denmark. Moreover, in several countries where this party family has performed relatively well, parties improved their support between 2004 and 2014, with some exceptions being the Belgium VB, the Italians AN and LN and the Dutch PVV, which have oscillated in their results over the time period.

\section{Graph 2: Results of extreme right wing parties in elections for the European Parliament (2004-} 2014)

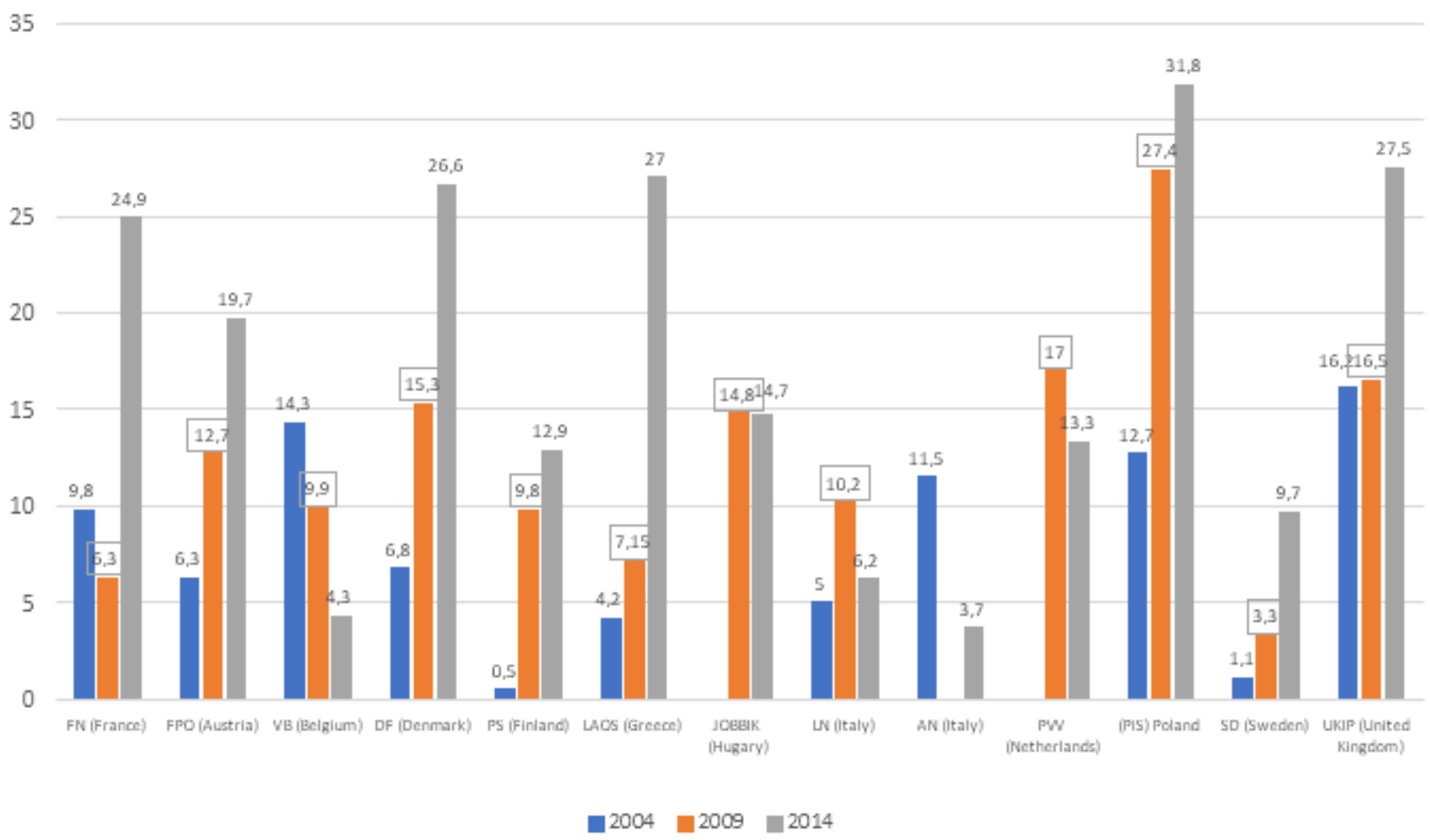

Source: ParlGov (http://www.parlgov.org)

Few are the countries in Europe that have presidential or semi-presidential regimes. Presidential elections are harder for smaller or challenging parties to compete and conquer relevant results, because they require substantive amounts of resources, a national-wide support, and alliance-formation (COX, 1997). As 
EXTREME RIGHTS PARTIES IN EUROPE TODAY: DEFINITION AND ELECTORAL PERFORMANCE

Aline Burni

majority elections, this means that they usually require a consolidated party organization, strong leadership and/or broader electoral alliances. A combination of such factors can be very important for the national projection of a party, and may require negotiations involving policy and office with diverse range of political actors. In old democracies, which usually have stablished systems, this could constraint opportunities encountered by extreme right parties, given that they often hold radical and rigid policy preferences, for instance regarding immigration issues. By its turn, their radicalism can be damaging for the image of potential partners. Furthermore, in consolidated democracies, traditional parties usually have more organizational advantages than younger parties (among them, extreme right ones), because they have a longer history behind them, more government experience, resources, a consolidated reputation and institutional strength.

These could be some of the reasons why extreme right parties have been, so far, generally weaker and quite absent from presidential elections, when compared to other types of competitions. In some countries, they have run with a competitive candidate in very few elections. In those cases, they may have obtained an impressive result in one occasion, but have drastically decreased their support in the following contest. An example of this has been the ATAKA party in Bulgaria, which got $21.49 \%$ in the first round in 2006 and $24.05 \%$ in the second round, but in 2011 its support fell to only $3.64 \%$.

Interestingly, it is the French $\mathrm{FN}$, which is considered a prototype of the extreme right party family (MUDDE, 2007; DE LANGE, 2008), being one of the oldest and most successful ones in terms of consistency of electoral results, that has been more frequently and strongly present in presidential disputes. The FN run a second round in two presidential elections, in 2002 and 2017. Candidate Marine Le Pen conquered a historical record of votes in the most recent dispute $\left(33.90 \%-2^{\text {nd }}\right.$ round in 2017).

By its turn, the Austrian FPO launched a very competitive candidate in 2016 and got $46.20 \%$ in the second round, but has previously been virtually absent in presidential disputes. Inserted in a proportional multiparty system, the FPO has so far privileged its performance on legislative elections. The FN, however, faces harder institutional and political constraints to get representation in nationally elected institutions. First, the two-round majority system in France encourages parties to establish electoral alliances. This has given place to a traditional two-bloc competition between left and right. Second, French mainstream parties have so far refused to cooperate with the extreme right party, establishing a cordon sanitaire against the FN - at least on the national level.

Finally, it is important to briefly raise attention to the fact that besides variation in the performance of extreme right parties across countries and among different types of elections, their vote share can present a very unequal geographical distribution inside the same country (JESUIT et al., 2009). This has been observed in almost all countries to which data has been found for this analysis, concerning results of recent legislative elections, as available on the European Elections Database (Austria, Belgium, Bulgaria, Cyprus, Denmark, Finland, Hungary, Italy, the Netherlands, Norway, Sweden, Switzerland, United Kingdom).

Table 2 below exemplifies how extreme right parties' results can vary within-country, both in nations where such parties are electorally stronger, and weaker. In some cases, their highest support in a certain subnational region can be twice as higher as their national average, for example in Belgium, where the VB concentrates its vote in the Flemish part of the country. In Italy, the internal differences of support to the LN also displays significant contrast, with a high concentration of its best results in the Northern part of the country (JESUIT et al., 2009). Similar territorial concentration trends have been observed for latest elections in France, Germany, the Netherlands and Austria (RODRIGUEZ-POSE, 2018).

\section{Table 2: Within-country variation of extreme right parties' legislative results}

\begin{tabular}{|c|c|c|c|c|c|}
\hline Country & Party & $\begin{array}{l}\text { Election } \\
\text { year }\end{array}$ & $\begin{array}{l}\text { National } \\
\text { vote }\end{array}$ & $\begin{array}{l}\text { Highest result } \\
\text { in } \\
\text { subnational } \\
\text { level }(\%)\end{array}$ & $\begin{array}{l}\text { Lowest result } \\
\text { in subnational } \\
\text { level }(\%)\end{array}$ \\
\hline Austria & FPO & 2008 & 17.54 & 22.6 & 7.49 \\
\hline Belgium & VB & 2010 & 7.76 & 16.15 & 0 \\
\hline Bulgaria & ATAKA & 2014 & 4.52 & 7.92 & 0.93 \\
\hline Cyprus & ELAM & 2011 & 1.08 & 2.04 & 0.67 \\
\hline
\end{tabular}


Aline Burni

\begin{tabular}{|llllll|}
\hline Denmark & DF & 2011 & 12.32 & 19.44 & 4.24 \\
\hline Finland & PS & 2011 & 19.04 & 25.27 & 0 \\
\hline Hungary & JOBBIK & 2010 & 16.67 & 27.2 & 10.84 \\
\hline Italy & LN & 2013 & 4.08 & 22.51 & 0.05 \\
\hline Netherlands & PVV & 2012 & 10.08 & 17.72 & 2.85 \\
\hline Norway & FRP & 2013 & 16.35 & 20.06 & 10.8 \\
\hline Sweden & SD & 2010 & 5.7 & 9.81 & 2.73 \\
\hline Switzerland & SVP & 2011 & 26.56 & 45.23 & 9.71 \\
\hline United Kingdom & UKIP & 2010 & 3.1 & 4.5 & 0 \\
\hline
\end{tabular}

Source: European Elections Database ${ }^{1}$

The geography of the vote for extreme right parties is not random. The territories or regions in which they concentrate their best results usually share important socio-economic characteristics. These regions are typically poorer and in economic decline, which makes Rodriguez-Pose (2018) argue that the support for populist parties (not only extreme right, but also from the left) have strong territorial, rather than social foundations.

Within-country geographical differences of support for extreme right parties have been studied by some authors (see LUBBERS et al., 2002; JESUIT et al., 2009; STOCKEMER; LAMONTAGNE, 2007; STOCKEMER, 2017), but to date this area of investigation has been dominated by national-level analysis, which implies several limitations (JESUIT et al., 2009). The reasons why such territories with specific characteristics leans towards extreme right parties is still a phenomenon to be unveiled, for example, as well as which sub-national factors are the most important drivers in this process. Besides that, the studies of my knowledge that focus on the sub-national level still focus almost exclusively on demand-side variables - such as socio-economic and contextual factors -, rather than supply-side variables - related to party characteristics and structures of competition at the local, or regional level. That said, it would be equally enriching to investigate the local and/or regional articulations taking place amongst elites, and party organizational differences in various territories as potential explanations for the extreme right fortunes.

\section{Concluding remarks}

Much has been said about the upsurge or reemergence of an extreme right-wing tendency in Europe and other old democracies, particularly following the Brexit vote (2016), Trump's election in the USA (2016) and the competitive presence of an extreme right presidential candidate in the second round of the Austrian (2016) and French (2017) contests. However, the emergence and progress of extreme right parties began about three decades ago in several countries, and this phenomenon does not follow a linear trajectory. The aim of this paper has been to provide a broad picture of the contemporary extreme right party family in Europe, both conceptually and empirically, using descriptive electoral data to illustrate their varying strength.

To do so, this work first discusses the differences of the current extreme right phenomenon, compared to former fascist and Nazi movements of the inter-war period, and then it proposes a party family definition grounded on the specialized literature. The definition I consider as the most adequate is not exactly new, but it applies some nuances to what has been previously argued by most prominent authors on the topic, emphasizing that extreme right parties are particularly worried with the cultural dimension of electoral competition, which makes identitarian politics one of their defining features, together with authoritarian values and a populist style.

Also, this paper describes recent electoral results of several extreme right parties in national legislative, presidential and European Parliament elections. Their vote shares across Europe shows that, although there is a general trend of progressive support over the last years, extreme right parties are not yet consolidated across every political system. Their support can be grounded on specific national context and institutional factors. Within-country descriptive data also suggests that there are important territorial factors 
EXTREME RIGHTS PARTIES IN EUROPE TODAY: DEFINITION AND ELECTORAL PERFORMANCE

Aline Burni

that should not be neglected in order to better understand the performance and prospects of such party family.

Therefore, there is a general trend of increasing support favoring extreme right parties in Europe, but there is also considerable variation across countries, among types of elections, and in the sub-national level. This is the case even more recently, after a few decades from their first emergence in the electoral scenario. This implies that, although there are common macro socio-economic factors explaining the emergence and growing support for extreme right parties in advanced democracies, there are also context-specific, institutional and party-level factors that must be taken into account.

Future research on this topic should investigate whether and how institutional variables create opportunities and constraints for extreme right parties, and what kinds of strategies payoff under diverse institutional designs and dynamics of party competition. Also, it seems clear that it is very important to nuance the vote share of extreme right parties in the sub-national level, trying to understand why they perform so differently inside the same country, while the regions in which they get their best results share similarities across countries. This should motivate new investigations interested in addressing why certain socio-economic conditions are more likely to benefit extreme right parties than others, and what is the mechanism behind the politicization of socio-economic grievances by this party family, for example. Finally, the subnational dynamics of party-competition should not be overlooked either, which means that analysts should investigate party characteristics, party strategies and elite-level factors operating on the local and regional levels.

(Received for Publication in November 2017)

(Presented Again in April 2018)

(Approved for Publication June 2018)

\section{To Cite this Article}

BURNI, Aline. Extreme Rights Parties in Europe Today: Definition and Electoral Performance. Revista Estudos Políticos: online jornal published twice a year by the Laboratory for the Hum(e)na Studies (Laboratório de Estudos Hum(e)anos, Fluminense Federal University, Brazil), Rio de Janeiro, Vol. 9 |N.1, pp. 124 -141 , July 2018.

At: http://revistaestudospoliticos.com/

\section{Notes}

1. Some of the data applied in the analysis in this publication are based on material from the "European Election Database". The data are collected from original sources, prepared and made available by the NSD - Norwegian Centre for Research Data (NSD). NSD are not responsible for the analyses/interpretation of the data presented here". Sources: Budge, I., Klingemann, H.-D., Volkens, A., Bara, J., Tanenbaum, E. with Fording, R.C., Hearl, D.J., Kim, H.M., McDonald, M. and Mendez, S. 2001. Mapping Policy Preferences. Estimates for Parties, Electors, and Governments 1945-1998. Oxford: Oxford University Press. ;

Klingemann, H.D., Volkens, A., Bara, J, Budge, I. McDonald, M. 2006. Mapping Policy Preferences II. Estimates for Parties, Electors, and Governments in Eastern Europe, the European Union and the OECD, 1990-2003. Oxford: Oxford University Press. ; Rose, R. and Munroe, N. 2009. Parties and Elections in New European Democracies. Colchester: ECPR Press. ; Colomer, J.M., ed. 2008. Comparative European Politics. New York: Routledge.

\section{Bibliographical References}


ALLEN, Trevor J. "All in the party family? Comparing far right voters in Western and Post-Communist Europe". Party Politics, 2015, vol. 12, no. 1, pp. 1-12.

ARZHEIMER, Kai. "Contextual Factors and the Extreme Right Vote in Western Europe, 1980-2002". American Journal of Political Science, 2009, vol. 53, no. 2, pp. 259-275.

BETZ, Hans-Georg. Radical Right-Wing Populism in Western Europe. Basingstoke: Macmillan, 1994.

BETZ, Hans-Georg. "The New Politics of Resentment: Radical RightWing Populist Parties in Western Europe". Comparative Politics, 1993, vol. 25 , no. 4, pp. 413-27.

BETZ, Hans-Georg; JOHNSON, Carol. "Against the current-stemming the tide: the nostalgic ideology of the contemporary radical populist right". Journal of Political Ideologies, 2004, vol. 9, no. 3, pp. 311-327. BORNSCHIER, Simon. Cleavage Politics and the Populist Right. Philadelphia: Temple University Press, 2010.

COX, Gary. Making Votes Count: Strategic Coordination in the World's Electoral Systems (Political Economy of Institutions and Decisions). Cambridge: Cambridge University Press, 1997.

DE LANGE, Sarah. From Pariah to Power: Explanations for the Government Participation of Radical Right-Wing Populist Parties in West European. 2008. PhD dissertation - University of Antwerp, Antwerp.

EATWELL, Roger. "The Nature of the Right: The Right as a Variety of Styles of Thought". In EATWELL, R. and O'SULLIVAN, N. (eds). The Nature of the Right: European and American Political Thought since 1789. London: Pinter, 1989, pp. 62-76.

FENNEMA, Meindert. "Some Conceptual Issues and Problems in the Comparison of Anti-Immigrant Parties in Western Europe". Party Politics, 1997, vol. 3, no. 4, pp. 473-92.

GIVENS, Terry. E. Voting Radical Right in Western Europe. Cambridge: Cambridge University Press, 2005.

GOLDER, Matt. "Far Right Parties in Europe". Annual Review of Political Science, 2016, vol. 19, no. 1, pp. 477-497.

HAINSWORTH, Paul. The Extreme Right in Western Europe. New York: Routledge, 2008.

HARRISON, Sarah; BRUTER, Michael. Mapping Extreme Right Ideology: An Empirical Geography of the European Extreme Right. Hampshire: Palgrave Macmillan, 2011.

HIX, Simon; LORD, Christopher. Political Parties in the European Union. London: Routledge, 1997.

IGNAZI, Piero. Extreme Right Parties in Western Europe. Oxford: Oxford University Press, 2006.

JESUIT, David K.; PARADOWSKI, Piotr R.; MAHLER, Vincent A. "Electoral support for extreme right-wing parties: A sub-national analysis of western European elections". Electoral Studies, vol. 28, no. 2, 2009, pp. 279-290.

KITSCHELT, Herbert; MCGANN, Anthony J. The Radical Right in Western Europe: A Comparative Analysis. Ann Arbor: University of Michigan Press, 1995. 
Aline Burni

KITSCHELT, Herbert. "Citizens, politicians, and party cartelization: Political representation and state failure in post-industrial democracies". European Journal of Political Research, 2000, vol. 37, no 2, pp. 149-179.

KLANDERMANS, Bert; MAYER, Nonna. (eds). Extreme Right Activists in Europe. Through the Magnifying Glass. London and New York: Routledge, 2006.

LAUDE, A. Droite Populiste et Radicale: un État des Lieux sur un Phénomène Singulier en Union Européenne, 06 de setembro de 2011. 78 p. Dissertação (Mestrado) - Institut d'Études Politiques de Lyon. Lyon, 2011.

LUBBERS, Marcel.; SHEEPERS, Peer. "French Front National voting: a micro and macro perspective". Ethnic and Racial Studies, 2002, vol. 25, no 1 , pp. 120-149.

LUBBERS, Marcel; GIJSBERTS, Merove; SCHEEPERS, Peer. "Extreme right-wing voting in Western Europe". European Journal of Political Research, vol. 41, no. 3, 2002, pp. 345-378.

MUDDE, Cas. The ideology of the extreme right. Manchester: Manchester University Press, 2000. MUDDE, Cas. Populist Radical Right Parties in Europe. Cambridge: Cambridge University Press, 2007. MUDDE, Cas. "The Study of Populist Radical Right Parties: Towards a Fourth Wave". Center for Research on Extremism, The Extreme Right, Hate Crime and Political Violence, University of Oslo, 2016, pp. 1-25. MUIS, Jasper; IMMERZEEL, Tim. "An overview and assessment of current scholarship on radical right-wing populism in Western Europe". International Society of Political Psychology (ISPP) Annual Meeting, Warsaw, July 13-16, 2016.

NORRIS, Pippa. Radical Right. Voters and Parties in the Electoral Market. Cambridge: Cambridge University Press, 2005.

REIF, Karlheinz; SCHMITT, Hermann. "Nine Second-Order National Elections - A Conceptual Framework for the Analysis of European Elections Results". European Journal of Political Research, 1980, vol. 8, no. 1 , pp. 3-44.

RODRIGUEZ-POSE, Andrés. "The revenge of the places that don't matter (and what to do about it)". Cambridge Journal of Regions, Economy and Society, vol. 11, no. 1, 2018, pp. 189-209 RODOGNO, David. "Le nouvel ordre fasciste en Méditerranée, 19401943: présupposés idéologiques, visions et velléités". Revue d'Histoire Moderne et Contemporaine, 2008, vol. 3, no. 55-3, 2008, pp. 138-156 ROODUIJN, Matthijs. "The rise of the populist radical right in Western Europe". European View, 2015, vol. 14, no. 1, pp. 3-11.

ROVNY, Jan. "Where do radical right parties stand? Position blurring in multidimensional competition". European Political Science Review, 2013, vol. 5, no. 1, pp. 1-26.

RYDGREN, Jens. "Immigration Sceptics, Xenophobes or Racists? Radical Right-Wing in Six West European Countries". European Journal of Political Research, 2008, vol. 47, no. 6, pp. 737- 765.

SCARROW, Susan E. "Politicians of Parties: Anti-Party Arguments as Weapons for Change in Germany". European Journal of Political Research, 1996, vol. 29, no. 3, pp. 297-317. 
STOCKEMER, Daniel; LAMONTAGNE, Bernadette. "Right-Wing Extremism in France - Departmental Differences in the Vote for the National Front". Romanian Journal of Political Science, 2007, vol. 7, no. 2, pp. 45-65.

STOCKEMER, Daniel. "The success of radical right-wing parties in Western European regions - new challenging findings". Journal of Contemporary European Studies, 2017, vol. 25, no. 1, pp. 41-56. TAGUIEFF, Pierre-Andre. Le Nouveau National-Populisme. Paris: Éditions CNRS, 2012.

PELINKA, Anton. Austria: Out of the Shadow of the Past. Boulder: Westview Press, 1998.

PERRINEAU, Pascal. Le retour du Front National. La Revue Socialiste, 2011, pp. 105-112, 2011.

PROWE, Diethelm. "'Classic' Fascism and the New Radical Right in Western Europe: Comparisons and Contrasts". Contemporary European History, 1994, vol. 3, no. 3, pp. 289-301.

VAN DER BRUG, Wouter; FENNEMA, Meidert. "Causes of voting for the radical right". International Journal of Public Opinion Research, 2007, vol. 19 , n.4, pp. 474-487. 